\title{
PENGARUH BAHAN TAMBAHAN MALTODEXTRIN DAN GOM ARAB TERHADAP KADAR TOTAL POLIFENOL DARI EKSTRAK TEH HIJAU (Camellia sinensis) SETELAH PENYIMPANAN
}

\author{
Rahmasia, Sartini, Asnah Marzuki \\ Fakultas Farmasi, Universitas Hasanuddin, Makassar
}

Kata Kunci :

Polifenol, ekstrak etanolik, bahan enkapsulasi, teh hijau (Camellia Sinensis)

\section{ABSTRAK}

Teh hijau (Camellia sinensis) mengandung senyawa polifenol utamanya epigallocatechin-3-gallate (EGCG), epigallatocatechin (EGC), epicatechin-3-gallate (ECG), dan epicatechin (EC) yang dapat berfungsi sebagai antioksidan. Senyawa polifenol tidak stabil pada temperatur, $\mathrm{pH}$ dan oksigen, sehingga ditambahkan bahan enkapsulasi maltodextrin dan gom arab untuk mempertahankan kadar polifenol selama masa penyimpanan. Penelitian ini bertujuan untuk mengetahui perbandingan bahan maltodextrin dan gom arab sebagai pengenkapsulasi dalam mempertahankan kadar polifenol dari ekstrak teh hijau selama masa penyimpanan. Ekstraksi dilakukan secara remaserasi menggunakan pelarut etanol $70 \%$ dengan perbandingan 1:5. Enkapsulasi ekstrak teh hijau menggunakan maltodextrin dan gom arab, perbandingan ekstrak teh hijau dengan enkapsulasi yaitu 1:5, 1:1 dan 1:2. Pengujian kadar total polifenol menggunakan metode spektrofotometri UV-Vis dengan larutan standar asam galat. Hasil penelitian menunjukkan bahwa enkapsulasi ekstrak teh hijau dapat mempengaruhi kadar total polifenol.

\section{PENDAHULUAN}

Tanaman teh (Camellia sinensis) merupakan tanaman yang banyak dibudidayakan di Indonesia. Salah satu produk dari teh antara lain teh hijau, teh hitam, teh putih dan teh oolong, Teh hijau dalam pembuatannya tidak mengalami fermentasi. Kandungan senyawa terbesar dalam teh adalah flavonoid. Flavonoid adalah senyawa polifenol yang berpotensi sebagai antioksidan dan mempunyai bioktivitas sebagai obat yang terdapat pada tanaman seperti sayuran, buah-buahan, kacang-kacangan, biji-bijian, akar dan minuman seperti teh dan anggur (1). Polifenol yang paling banyak ditemukan dalam teh hijau adalah flavonol, yaitu katekin. Katekin dalam teh hijau terdiri atas epigallocatechin-3-gallate (EGCG), epigallatocatechin (EGC), epicatechin-3-gallate (ECG), dan epicatechin (EC) $(2,3)$

\section{Masuk 07-12-2018 \\ Revisi 30-01-2019 \\ Diterima 30-01-2019 \\ Korespondensi \\ Sartini \\ sardj@yahoo.com \\ Copyright \\ (C) 2018 Majalah Farmasi Farmakologi Fakultas \\ Farmasi - Makassar}

Diterbitkan tanggal 30-04-2019

Dapat Diakses Daring Pada:

http://journal.unhas.ac.id /index.php/mff
Salah satu senyawa yang berfungsi sebagai antioksidan adalah Epigallocatechingallate (EGCG) $(4,5)$. Senyawa antioksidan alami polifenolik ini adalah multifungsional dan dapat beraksi sebagai pereduksi, penangkap radikal bebas, pengkelat logam, pencegahan kanker dan penyakit jantung (6). antiinfeksi, antivirus, antifungi dan antibakteri (7).

Senyawa EGCG tidak stabil terhadap temperatur, $\mathrm{pH}$ dan oksigen $(8,9,10)$, sehingga dilakukan pengujian dengan menambahkan bahan enkapsulasi untuk melindungi komponenkomponen penting, seperti antioksidan dan mempertahankan permeabilitas oksigen pada dinding matriks (11). Bahan tambahan enkapsulan, seperti gom arab dan maltodekstrin. Gom arab dapat meningkatkan viskositas jika dilarutkan dalam air, sehingga membantu menstabilkan dispersi komponen-komponen yang kurang larut, selain itu gom arab membentuk lapisan dan mengikat flavor (9). Maltodextrin dapat mencengah terjadinya pelepasan komponen kimia, melindungi komponen-komponen penting, seperti antioksidan, vitamin dan warna (12). Maltodekstrin mempunyai berbagai fungsi, seperti pembentukan film, pengikat rasa dan lemak, mereduksi permeabilitas oksigen pada dinding matriks (13). Penambahan bahan enkapsulasi dengan metode pengeringan beku (freeze drying). Di dalam metode pengeringan beku terdapat proses pengeluaran air dalam keadaan beku dari suatu produk melalui cara sublimasi, yang dilakukan pada suhu dan tekanan rendah (14).

Berdasarkan uraian diatas, maka dilakukan penelitian untuk mengetahui pengaruh enkapsulasi maltodextrin dan gom arab terhadap kadar polifenol selama masa penyimpanan. Diharapkan hasil penelitian ini nantinya dapat memberikan sumbangan teori ilmiah mengenai pemanfaatan senyawa bahan alam yang berasal dari teh hijau sebagai antioksidan.

\section{METODE PENELITIAN}

\section{Alat dan Bahan}

Alat-alat yang digunakan adalah alat-alat gelas yang biasa digunakan di laboratorium, freeze dryer, dan spektrofotometer UV-Vis.

Bahan yang digunakan adalah aquadest, alkohol, Produk teh hijau, aquades, etanol 70\%, DPPH, pelarut folin-ciocalteu, metanol PA, etanol PA, Natrium Asetat, 5\%. 


\section{Prosedur Kerja}

\section{Pembuatan Ekstrak Teh Hijau}

Ekstraksi dilakukan dengan metode maserasi (15) menggunakan modifikasi pada konsentrasi pelarut etanol. Sampel teh hijau ditimbang 0,1 kg, kemudian diremaserasi dengan pelarut $n$-heksan dengan perbandingan 1:5 selama 3 hari, kemudian disaring. Ampas teh hijau yang tidak larut nheksan diremaserasi dengan etanol $70 \%$ dengan perbandingan sampel dan pelarut 1:5 selama 3 hari. Hasil maserasi dikumpulkan kemudian diuapkan menggunakan rotavapor hingga diperoleh ekstrak etanol teh hijau yang kental

\section{Enkapsulasi Ekstrak Teh Hijau}

Enkapsulasi dilakukan dengan beberapa perbandingan yang tertera pada tabel 1 .

\begin{tabular}{ccc} 
Tabel 1. Perbandingan antara ekstrak teh hijau dengan enkapsulasi \\
\hline $\begin{array}{c}\text { Perbandingan } \\
\text { ekstrak: } \\
\text { enkapsulan }\end{array}$ & Perbandingan Enkapsulan \\
\cline { 2 - 3 } $1: 1$ & 0,8 & gum arab \\
\hline & 0,6 & 0 \\
& 2 & 0,2 \\
$1: 2$ & 1,6 & 0,4 \\
\hline & 1,2 & 0 \\
& 5 & 0,4 \\
& 4 & 0,8 \\
\hline & 3 & 0 \\
& & 2 \\
\hline
\end{tabular}

Sampel ditimbang 0,1 g, kemudian dilarutkan dengan aquades $10 \mathrm{~mL}$, ditambahkan maltodextrin dan gom arab, kemudian dihomogenizer dengan kecepatan $3000 \mathrm{rpm}$ dan di freezer drying.

Pengeringan dilakukan dengan metode freezer drying pada $40{ }^{\circ} \mathrm{C}$ Larutan enkapsulasi teh hijau yang telah siap dimasukkan kedalam freezer hingga larutan membeku. Kemudian dimasukkan kedalam freeze-dryer yang sudah dihidupkan. Selanjutnya, keran pengatur tekanan dibuka agar uap air yang tersublim dapat berpindah dari bahan. Proses ini berlangsung hingga bahan benar-benar kering.

\section{Penqujian Aktivitas Antioksidan}

\section{Pembuatan DPPH}

Larutan DPPH 0,4 mM sebanyak $1 \mathrm{~mL}$ dimasukkan ke dalam labu tentukur $5 \mathrm{~mL}$ lalu ditambahkan metanol p.a diinkubasi dalam ruangan gelap selama 30 menit; selanjutnya dituang ke dalam tabung kuvet dan diukur pada panjang gelombang 400-800 nm menggunakan spektrofotometer UV-Vis. Selanjutnya dibuat larutan stok asam askorbat $1000 \mathrm{bpj}$, kemudian dibuat seri konsentrasi 2 bpj, 4 bpj, 6 bpj, 8 bpj dan $10 \mathrm{bpj}$ dan dimasukkan dalam labu tentukur $5 \mathrm{~mL}$ dengan penambahan $1 \mathrm{~mL}$ larutan DPPH 0,4 mM dan dicukupkan dengan metanol p.a hingga $5 \mathrm{~mL}$. Pengukuran dilakukan dengan cara masing-masing seri konsentrasi larutan asam askorbat yang telah dibuat diinkubasi dalam ruangan gelap selama 30 menit; selanjutnya dituang ke dalam tabung kuvet dan diukur pada panjang gelombang maksimum menggunakan spektrofotometer UV-Vis. Sedangkan untuk ekstrak etanol teh hijau dibuat larutan stok $1000 \mathrm{bpj}$, kemudian dibuat seri konsentrasi 100, 200, 300, 400, 500 dan 600 bpj dan dilakukan Pengukuran dengan cara yang sama seperti pada pengukuran larutan pembanding asam askorbat (16).
Penentuan Persen Aktivitas Penghambatan DPPH

Aktivitas antioksidan larutan uji dapat diketahui berdasarkan tingkat kapasitasnya dalam menghambat radikal bebas DPPH melalui hasil serapan (17). Untuk menghitung persen aktivitas penghambatan DPPH digunakan rumus:

$$
\% \text { Aktivitas Penghambatan }=\frac{A_{0}-A_{1}}{A_{0}} \times 100 \%
$$

Keterangan $\quad: \mathrm{A}_{0}=$ serapan DPPH

$$
\mathrm{A}_{1}=\text { serapan sampel }
$$

\section{Penentuan nilai I $C_{50}$ (Inhibitory Concentration)}

Konsentrasi sampel dan persen aktivitas penghambatan yang diperoleh diplot masing-masing pada sumbu X dan sumbu Y pada persamaan regresi linear. Persamaan tersebut digunakan untuk menentukan nilai $\mathrm{IC}_{50}$ dari masing-masing sampel yang dinyatakan dengan nilai y sebesar 50 dan nilai $\mathrm{x}$ yang akan diperoleh sebagai $\mathrm{IC}_{50}$.

Penentuan nilai All (Antioxidant Activity Index)

Nilai AAI menentukan sifat kekuatan antioksidan, penentuannya dengan cara konsentrasi DPPH (bpj) yang digunakan dalam uji dibagi dengan nilai $\mathrm{IC}_{50}$ (bpj) yang diperoleh (17).

\section{Analisis Dato}

Data yang diperoleh diolah secara statistik menggunakan software SPSS. Data yang berdistribusi normal dilakukan uji ANOVA, sedangkan data yang tidak berdistribusi normal maka dilakukan uji Kruskal.

\section{Analisis Kadar Polifenol Total}

Sampel ditimbang 0,1 g dilarutkan dalam metanol PA dan dimasukkan dalam labu tentukur $10 \mathrm{~mL}$, dipipet $0,5 \mathrm{~mL}$ dimasukkan kedalam labu tentukur $5 \mathrm{~mL}$, dipipet $0,2 \mathrm{~mL}$ dimasukkan dalam labu tentukur $5 \mathrm{~mL}$ ditambahkan $2 \mathrm{~mL}$ $\mathrm{NaoH} 1 \mathrm{~N}$ dan 2,5 mL Folin ciocalteu dan di add dengan aquades sampai batas tanda, kemudian diinkubasi selama 1 jam. serapan diukur dengan spektrofotometri pada panjang gelombang maksimum $\lambda$ maks $648 \mathrm{~nm}$.

\section{HASIL DAN PEMBAHASAN}

Ekstraksi dilakukan secara maserasi menggunakan pelarut etanol 70\% dengan perbandingan 1:5 selama 3 x 24 jam, selanjutnya dipekatkan menggunakan rotavapor, hingga diperoleh ekstrak etanol teh hijau yang kental dengan bobot ekstrak 49,9 g dan persen rendamen 4,99\% dari $1 \mathrm{~kg}$ bobot sampel kering.

Hasil ekstrak teh hijau ini lebih kecil dibandingkan penelitian yang dilakukan oleh Sundari (18) yaitu sebesar 37,5\% dengan menggunakan metode ekstraksi dan cairan penyari/pelarut yang sama yaitu etanol $70 \%$ dan penelitian yang dilakukan oleh Andaryekti (19) yaitu sebesar 32,57 \% dengan menggunakan metode ekstraksi dan cairan penyari/pelarut yang sama yaitu etanol $70 \%$. Perbedaan ini mungkin dikarenakan tempat tumbuh teh hijau yang berbedah (20).

Dilakukan uji aktivitas antioksidan dan menggunakan spektrofotometer dengan pereaksi DPPH. DPPH digunakan untuk mengevaluasi aktivitas antioksidan dari beberapa senyawa alami. Hasil uji aktivitas antioksidan ekstrak teh hijau yaitu IC50 $41,073 \mu \mathrm{g} / \mathrm{mL}$, ekstrak teh hijau memiliki tingkat aktivitas antioksidan yang tergolongan sangat kuat karena nilai IC50 kurang dari $<50 \mu \mathrm{g} / \mathrm{mL}$ (Pramesti, 2013).

Hasil pengujian antioksidan teh hijau ini lebih besar dibandingkan penelitian yand dilakukan oleh Kusmita (22) yaitu sebesar IC50 $=21,44 \mu \mathrm{g} / \mathrm{mL}$ dengan menggunakan metode ekstraksi dan cairan penyari/pelarut yang sama yaitu 
etanol 70\%. Perbedaan ini terjadi dikarenakan beberapa faktor yaitu waktu penyimpanan dan tempat tumbuh yang berbedah. (23).

Berdasarkan hasil pengukuran kurva baku kadar polifenol diperoleh persamaan regresi linier yaitu $y=0,0776 \mathrm{x}-0,0698$ dengan nilai koefisien kolerasi $\mathrm{R} 2=0,994$. Nilai $\mathrm{R}$ yang mendekati 1 menunjukkan kurva kalibrasi linier dan terdapat hubungan antara konsentrasi larutan asam galat dengan nilai serapan (absorbansi). Setelah itu dilakukan pengukuran kadar polifenol ekstrak etanol teh hijau, sehingga didapatkan kadar rata-rata total polifenol yang terlihat pada tabel 2 .

Tabel 2. Kadar rata-rata total flavonoid dan polifenol ekstrak etano teh hijau selama masa penyimpanan

\begin{tabular}{cccc}
\hline \multirow{2}{*}{ Senyawa } & \multicolumn{3}{c}{ Waktu penyimpanan } \\
\cline { 2 - 4 } & Minggu ke 0 & Minggu ke 2 & Minggu ke 4 \\
\hline Polifenol & $22,12 \%$ & $21,89 \%$ & $20,45 \%$ \\
\hline
\end{tabular}

Hasil kadar rata-rata total polifenol ini lebih kecil dibandingkan penelitian yang dilakukan oleh Archana (24) yaitu sebesar 26,25 \% dengan menggunakan metode ekstraksi dan cairan penyari/pelarut yang sama yaitu etanol, Adapun faktor yang mempengaruhi jumlah kadar polifenol total yang berbeda-beda dipengaruhi oleh tempat tumbuh yang berbedah (20).

Hasil perbandingan enkapsulasi ekstrak etanol teh hijau pada kadar polifenol total terhadap waktu penyimpanan yang terlihat pada gambar 1

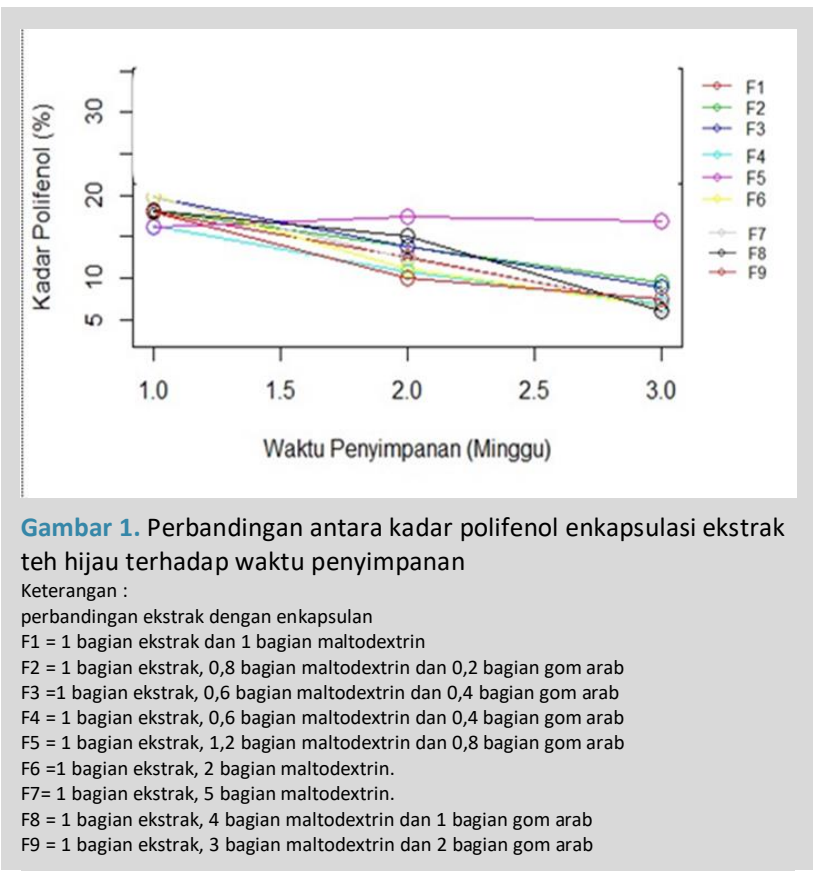

Gambar 1. menunjukkan bahwa formula F5 memiliki kadar total polifenol yang stabil selama 4 minggu penyimpanan dibandingkan dengan 8 formula lainnya.

Berdasarkan tabel 3. Menunjukkan bahwa dengan penggunaan 1 bagian ekstrak teh hijau dan 2 bagian enkapsulasi dengan perbandingan enkapsulan 1,2 bagian maltodextrin dan 0,8 gom arab (F5), memiliki \% penurunan kadar total polifenol $0,94 \%$ yang stabil selama masa penyimpanan 4 minggu.

Dari berbagai penelitian diketahui bahwa ada beberapa senyawa golongan flavonoid dan polifenol yang sensitif terhadap suhu panas dan hal ini dapat menyebabkan senyawa polifenol dari ekstrak teh hijau tersebut mengalami degradasi kimia (penurunan kadar) selama masa penyimpanan (25), sehingga perlu ditambahkan bahan tambahan enkapsulasi yaitu maltodextrin dan gom arab untuk melindungi senyawa polifenol dari ekstrak teh hijau (26), sehingga dapat stabil (tidak mengalami penurunan kadar flavonoid dan polifenol) selama masa penyimpanan.

\begin{tabular}{lcc} 
Tabel 2. Kadar rata-rata total flavonoid dan polifenol ekstrak etanol \\
teh hijau selama masa penyimpanan \\
\hline & \% Penurunan Kadar Polifenol \\
\cline { 2 - 3 } Formula & Minggu & Minggu \\
& $0-2$ & $0-4$ \\
\hline F0 & 1,02 & 6,57 \\
F1 & 29,94 & 42,82 \\
F2 & 24,08 & 31,48 \\
F3 & 30,15 & 35,53 \\
F4 & 34,77 & 35,77 \\
F5 & $-5,63$ & 0,94 \\
F6 & 44,67 & 41,09 \\
F7 & 37,26 & 46,47 \\
F8 & 17,01 & 60,13 \\
F9 & 43,90 & 25,98
\end{tabular}

Untuk melihat adanya pengaruh enkapsulasi selama masa penyimpanan $(0,2$ dan 4 minggu) terhadap kadar polifenol dan flavonoid ekstrak etanol teh hijau, digunakan salah satu metode analisis statistik, yaitu analisis variasi (ANOVA) dan uji kruskal.

Hasil uji statistik variasi (ANOVA) menunjukkan bahwa kadar polifenol ekstraksi teh hijau pada F5 terenkapsulasi maltodextrin dan gom arab tidak berbedah nyata tiap minggu dengan nilai signifikansi $0,072(P>0,05)$.

Hasil uji kruskal menunjukkan bahwa kadar polifenol ekstraksi teh hijau pada F5 terenkapsulasi maltodextrin dan gom arab tidak berbedah nyata tiap minggu dengan nilai signifikansi 0,433 $(\mathrm{P}>0,05)$.

\section{KESIMPULAN}

Berdasarkan hasil penelitian yang diperoleh, dapat disimpulkan bahwa ada pengaruh enkapsulasi ekstrak teh hijau terhadap kadar total polifenol setelah penyimpanan. Enkapsulasi yang stabil selama masa penyimpanan 4 minggu adalah formula F5 yaitu 1 bagian ekstrak dan 2 bagian enkapsulasi (1,8 bagian maltodextrin dan 0,2 bagian gom arab)

\section{UCAPAN TERIMA KASIH}

Penulis mengucapkan terima kasih kepada Allah swt, Penulis juga berterima kasih kepada para dosen dan staf Fakultas Farmasi Universitas Hasanuddin atas dukungan moril dan sarana selama penulis melakukan penelitian

\section{DAFTAR PUSTAKA}

1. Bhagwat, S., Beecher, G. R., Haytowitz, D. B., Holden, J. M., Dwyer, J., Peterson, J. .. \& Balentine, D. A. 2003. Flavonoid composition of tea: Comparison of black and green teas. Agricultural Research Service. USDA database for the flavonoid content of selected foods.

2. Jigisha A, Nishant R, Navin K, Pankaj G. Green tea: a magical herb with miraculous outcomes. Int. Res. J. Pharm. 2012; 3:139-48.

3. Si W, Gong J, Tsao R, Kalab M, Yang R, Yin Y. Bioassay-guided purification and identification of antimicrobial components in Chinese green tea extract. J Chromatogr A. 2006;1125:204e210.

4. Kusmiyati, M., Sudaryat, Y, Lutfiah, I.A., Rustamsyah, A., \& Rohdiana, D. 2015. Aktivitas antioksidan, kadar fenol total dan flavonoid total dalam teh hiaju (camellia sinensis(L)O. Kuntze) asal tiga perkebunan Jawa Barat. Jurnal Penelitian Teh dan Kina, 18(2),101-106.

5. Ishii, T., Mori, T., Tanaka, T., Mizuno, D., Yamaji, R., Kumazawa, S., .. \& Akagawa, M. 2008. Covalent modification of proteins by green tea polyphenol (-)-epigallocatechin-3-gallate through autoxidation. Free Radical Biology and Medicine, 45(10), 1384-1394. 
6. Chung, F-L. 2002. Tea and cancer prevention: Studies in animals and humans. Third International Scientific Synposiumbon Tea and Human Health: Role of Flavonoids in the Diet, Sept. 23,

7. Steinmann, J., Buer, J., Pietschmann, T., \& Steinmann, E. 2013. Antiinfective properties of epigallocatechin-3-gallate (EGCG), a component of green tea. British journal of pharmacology, 168(5), 1059-1073.

8. Sang, S., Yang, I., Buckley, B., Ho, C. T., \& Yang, C. S. 2007. Autoxidative quinone formation in vitro and metabolite formation in vivo from tea polyphenol (-)-epigallocatechin-3-gallate: studied by real-time mass spectrometry combined with tandem mass ion mapping. Free Radical Biology and Medicine, 43(3), 362-371.

9. Sang, S., Lee, M. J., Hou, Z., Ho, C. T., \& Yang, C. S. 2005. Stability of tea polyphenol (-)-epigallocatechin-3-gallate and formation of dimers and epimers under common experimental conditions. Journal of agricultura and food chemistry, 53(24), 9478-948 4.

10. Su, Y. L., Leung, L. K., Huang, Y., \& Chen, Z. Y. 2003. Stability of tea theaflavins and catechins. Food Chemistry, 83(2), 189-195.

11. Drusch, S., Serfert, Y., Van Den Heuvel, A., \& Schwarz, K. 2006 Physicochemical characterization and oxidative stability of fish oi encapsulated in an amorphous matrix containing trehalose. Food Research International, 39, 807-815.

12. Man, Y. B. C., Irwandi, J., and Abdullah, W. J. W. 1999. Effect of different types of maltodextrin and drying methods on physic-chemical and sensory properties of encapsulated durian flavor. Journal of the Science of Food and agliculture. Vol 79. Issue 8. Pp 1075-1080.

13. Bae, E.K., \& S.J. Lee,. 2008. Microencapsulation of avocado oil by spray drying using whey protein and maltodextrin. Journal of Microencapsulation, 25(8): 549-560.

14. Hariyadi, P., 2013, Freeze Drying Technology: for Better Quality \& Flavor of Dried Products, Foodreview Indonesia, Vol. VIII/No.2.

15. Sartini, Djide, M. N., \& Alam, G., 2011. Ekstraksi Komponen Bioaktif dari Limbah Kulit Buah Kakao dan Pengaruhnya Terhadap Aktivitas Antioksidan Dan Antimikroba, Majalah Obat Tradisional, (Online).
16. Molyneux, P. 2004. The Use of The Stable Free Radical Diphenylpicrylhydrazyl (DPPH) For Estimating Antioxidant Activity. Songklanakarin Journal Science and Technology. 26 (2) : 211-219

17. Blois, M.S. 1958. Antioxidant determinations by the use of a stable free radical. Nature 181: 1199-1200.

18. Sundari, D., Nuratmi,B., \& Winarmo, M. 2009. Toksisitas Akut (LD50 Dan Uji Gelagat Ekstrak Daun Teh Hijau (Camellia Sinensis (Linn). Kunze) Pada Mencit. Media Penelitian Dan Pengembangan Kesehatan,19(4Des)

19. Andaryekti, R., Mufrod, M.,\& Minisih, S. 2015. Pengaruh Basis Gel Sediaan Masker Ekstrak Daun Teh Hijau (Camellia Sinensis) Pada Karakteristik Fisik Dan Aktivitas Bakteri Staphylococcus Aureus ATCC 25923. Majalah Farmaseutik, 11(2), 294-299

20. Syah A. 2006 Taklukkan Penyakit dengan Teh Hijau. Jakarta: Argo Media Pustaka: 14-17: 59-65.

21. Pramesti R. 2013. Aktivitas Antioksidan Ekstrak Rumput Laut Caulerpa serrulata dengan Metode DPPH (1,1 difenil 5 pikrihidrazil). Buletin Oseanografi Marina, April 2013 Vol. 2 7-15.

22. Kusmita, L., Puspitaningrum, I., \& Limantara, L. 2015. Identification, isolation and antioxidant activity of pheophytin from green tea (Camellia sinen sis (L.) Kuntze). Procedia Chemistry, 14, 232-238

23. Hartono A. Teh dan Khasiatnya bagi Kesehatan. Jakarta: Kanisius. 2002. 25-25

24. Archana, S., \& Abraham, J. 2011. Comparative analysis of antimicrobial activity of leaf extracts from fresh green tea, commercial green tea and black tea on pathogens. Journal of Applied Pharmaceutical Science, 1(8), 149.

25. Mrmorsamin, J.M, Pavloic, A.N, Veljkovic, J.N. 2015. The Effect of Storage Temperatur and Thermal Processing on Cathecins, Procyanidins, and Total Flavonoid Stability in Commercially Available Cocoa Powder. Physics, Chemistry and Technology Vol. 13 No.1 p 39-49

26. Finotelli \& Rocha-Leao. 2010. Microencapsulation of avocado oil by spray-drying using whey protein and maltodextrin. Journal of Microencapsulation, 25(8): 549-558 